Nig. J. Biotech. Vol. 36(2): 62 - 76 (Dec 2019)

ISSN: 01891731

Available online at

http://www.ajol.info/index.php/njb/index

and www.biotechsocietynigeria.org

DOI: https://dx.doi.org/10.4314/njb.v36i2.8

\title{
Phylogenetic analysis of hydrocarbon degrading bacteria associated with crude oil polluted soil from Mesogar community, Delta State, Nigeria.
}

\author{
Olukunle, $\mathbf{O}$. F. \\ Department of Biotechnology, Federal University of Technology, P. M. B. Akure, Nigeria
}

\begin{abstract}
This study was carried out to isolate hydrocarbon-degrading bacteria associated with oil polluted soil samples collected from Mesogar community of Delta State, Nigeria. The samples were aseptically collected and the bacteria isolated according to standard microbiological techniques. The isolates with hydrocarbon biodegradative ability were screened on MSM supplemented with $2 \%$ crude oil using spectrophotometric method. The amount of crude oil degraded by the highest hydrocarbon degrader was determined using gas chromatographic (GC) assay. A total of seven bacterial isolates were molecularly identified using the 16S rRNA gene sequencing method. The sequences were compared to those deposited in NCBI using the basic local alignment tool (BLAST) algorithm. Phylogenetic analysis of 16S rRNA gene sequences was carried out to determine the evolutionary relationships of the isolated bacterial species. The isolates were identified to have remote similarities with A/caligenes faecalis SH179a, A/caligenes faecalis subsp. Phenolicus, Bacillus thuringiensis serovar konkukian, Ochrobactrum anthropi, A/caligenes faecalis SH179b, Uncultured soil bacterium clone and Alcaligenes faecalis IVN45. Strain OFBR 4 had the highest degrading ability. The use of molecular methods for rapid and accurate detection of diverse strains of hydrocarbon-degraders is of utmost necessity in bioremediation.
\end{abstract}

Keywords: Phylogenetic analysis, oil polluted soil, biodegradative, hydrocarbon degrader, 16S rRNA gene and crude oil.

\section{Introduction}

The wide spread contamination of most natural environments with petroleum products in the Niger Delta region of Nigeria is as a result of daily increasing petroleum exploration, refining and other related activities (Romanus et al. 2015). This area is particularly endowed with crude oil and natural gas deposits which are the main source of energy and foreign exchange earnings in Nigeria (Oboh et al. 2006; Oyetunji, 2013). Oil spill occur both on-shore and offshore (Olukunle, 2013) during exploration and transportation. Transportation of oil from points of exploitation and refinery to consumption locations involves the risk of accidental oil spills, which can cause severe damage to ecosystems (Chang et al. 2014). Offshore oil spills contaminate coastal environments and affect aquatic life (Osuagwu \& Olaifa, 2018). It causes constant threat to farmlands, forest trees, crop plants and other vegetations by adversely affecting soil fertility and altering of soil physicochemical and microbiological properties (Boboye et al. 2010). Surface and underground water are also polluted causing damage to humans and the ecosystem as a result of contamination of drinking water, poisoning and killing of aquatic life. Presence of oil in water reduces the amount of dissolved oxygen available. Shift in microbial populations are noticeable at polluted sites (Hamzah et al. 2010). The hydrocarbons spread on the ground water 
surface and partition into groundwater. During raining season, polycyclic aromatic hydrocarbons (PAHs) in crude oil towards water bodies and enter into human food chain. PAHs are hazardous compounds which can cause serious diseases such as cancer, asthma and hormonal diseases. Some species have their population either increased or decreased while others go into extinction, leading to ecological imbalance (El Hanafy et al. 2015).

It is an emerging environmental challenge arising from the activities of petrochemical industries and other anthropogenic activities (Unimke et al. 2018). Three major methods are widely known to be employed for cleaning up oil spill. These methods are physical, chemical and biological techniques. Physical and chemical techniques such as volatilization, leaching, chemical and photo-oxidation have been used in the past. They are often effective in reducing the environmental level of polyaromatic hydrocarbons. However, they are usually expensive and labor intensive and often involve the risk of spreading the pollution since the waste would require being disposed elsewhere. Also, the chemicals used in the process may harm the surrounding environment (Saleh et al. 2003) and also affect the natural biological communities. Biological technique (bioremediation) appears to be the most promising of all methods employed for cleaning oil spill.

According to Willey et al. (2008), bioremediation is the use of microorganisms to remove pollutants. Olukunle \& Boboye (2012), defined bioremediation as the application of living organisms or their enzymes to provide an effective alternative to restore the environment altered by contaminants to its original condition. It provides an effective and efficient strategy to speed up the clean-up process (Hamzah et al. 2011) because the occasional oil spill forms a source of carbon surplus for hydrocarbon degraders. Hydrocarbons are energy-rich compounds (Varjani, 2017). Moreover, bioremediation methods are characterized by low cost, high efficiency, environmental friendliness and simplicity technology for long term restoration of oil contaminated sites (Asadirad et al. 2016). Harmless products such as $\mathrm{CO}_{2}, \mathrm{H}_{2} \mathrm{O}$, and other inorganic compounds are released as a result of mineralization of hydrocarbons (Fathepure, 2014). Microbial degradation appears to be the most environmentally friendly method of removing oil spill since other methods such as surfactant washing and incineration lead to introduction of more toxic compounds to the environment. It had been known to be carried out by diverse bacterial populations, especially by the Pseudomonas spp. (Jyothi et al. 2012) and fungi. Mostly reported genera of hydrocarbon-degraders include Pseudomonas, Acinetobacter, Nocardia, Vibrio, Achromonobacter, Bacillus and Micrococcus (Saleh et al. 2003). Microbial hydrocarbon degradation involves the manipulation of environmental parameters to allow microbial growth and degradation activities to proceed at a faster rate (Ainon et al. 2010). Using indigenous microorganisms for bioremediation of polluted sites is more effective than introducing foreign microorganisms to degrade hydrocarbons. The reason is not far-fetched. The indigenous microorganisms are already adapted for survival and proliferation in that environment (Gopinathan et al. 2012). As a result, there is a well-established direct correlation between microbial diversity and the presence of hydrocarbons in any oil-contaminated sites (Kachienga et al. 2018). The activities of biodegraders in a bioreactor can be monitored through gas chromatography coupled with mass spectrometry. The gas chromatography separates the compounds from each other, while the mass spectrometer helps to identify them based on their fragmentation pattern (JeromeJeyakumar, 2013).

The development of molecular techniques to investigate ecological microbial communities has provided microbiologist with new techniques to study microorganisms. The increased ease with which molecular analysis can be carried out has led to an explosion in sequencing of ribosomal DNA (rDNA) and ribosomal RNA (rRNA) from different bacterial species and strains from different environments. This has allowed the construction of relevant sequence databases (Vivek \& Debajit, 2011). The identity of novel sequences and diversity in environmental samples are discovered through molecular identification that involves 16SrRNA (Olukunle \& Boboye, 2012).

Microbes from sediments previously contaminated with oil are able to metabolize oil faster than those from sediments that had never been contaminated. The inheritance of oil-degrading ability is explained in a concept known as 'genetic adaptation'. This means 
that if a species of bacteria is exposed to oil and metabolizes it, the next generations inherit that ability. This has been reported in a particular species of Vibrio in the Northwestern Gulf of Mexico (Biello, 2010). This has led to genetic diversity and development of new strains. The gene encoding for hydrocarbon degradation is present in all biodegraders of oil (Boboye et al. 2010) hence, a degree of closeness or relatedness in their genome. Phylogenetic analysis generates branching, treelike diagrams that represent an estimated pedigree of the inherited relationship among molecule, organism or both. Phylogenetic tree shows how the families have been deriving during evolution (Gautum \& Vimal, 2014).

In this study, indigenous oil degrading bacteria from oil polluted sites in Delta State, Nigeria, were isolated and identified using molecular techniques which involves DNA isolation, PCR amplification of $16 \mathrm{~S}$ rRNA gene, sequencing and phylogenetic analysis of partial 16S rRNA fragments.

\section{Materials and Methods}

Sampling sites and collection of samples

Oil-contaminated soil samples were collected from Mesogar Community, Warri South Local Government Area of Delta State, Nigeria and an uncontaminated soil sample that serves as control. The soil samples (S1 - S4) were collected aseptically into sterile cellophane bags and transported to the Microbiology Laboratory of the Federal University of Technology, Akure, Nigeria.

Enumeration of bacteria from soil samples Serial dilution was carried out on the soil samples. An aliquot of the diluent was seeded into growth medium in sterile Petri dishes containing nutrient agar (NA). The plates were then incubated at $37^{\circ} \mathrm{C}$ for 24 hours for the NA plates. Counting was done using colony counter (TT-02 colony counter, Techmel and Techmel, USA).

\section{Sub culturing for pure microbial isolates}

From the mixed culture on the plates, each microbial colony was sub cultured on sterile Petri dishes containing nutrient agar. This was done by using a sterile inoculating loop to transfer each colony onto the fresh sterile NA plates using the streak technique. The plates were incubated at $37^{\circ} \mathrm{C}$ for 24 hours.
Biochemical and morphological identification of bacterial isolates

Individual colonies were identified by morphological and biochemical features using the Bergey's Manual of Determinative Bacteriology.

\section{Preservation of stock culture}

The slant technique of culture preservation was used to preserve the stock culture. Double strength culture media was prepared and poured into McCartney bottles. The bottles were set in a slanting position where they were allowed to gel. Then, with the aid of a sterile inoculating loop, an inoculum of each isolate was carefully transferred onto the solidified agar slant. This procedure was then carried out for all the pure cultures of isolates. The bottles were then incubated at $28^{\circ} \mathrm{C}$ for 24 hours and kept in the refrigerator until they were required.

\section{Enumeration of oil-degrading bacteria}

The mineral salt medium (MSM) as described by Jyothi et al. (2012) was used. The composition of the MSM is as follows: $\mathrm{K}_{2} \mathrm{HPO}_{4}$ $(1.8 \mathrm{~g} / \mathrm{L}) ; \mathrm{NH}_{4} \mathrm{Cl}(4 \mathrm{~g} / \mathrm{L}) ; \mathrm{MgSO}_{4} .7 \mathrm{H}_{2} \mathrm{O}(0.2$ $\mathrm{g} / \mathrm{L}) ; \mathrm{NaCl}(0.1 \mathrm{~g} / \mathrm{L}) ; \mathrm{Na}_{2} \mathrm{SO}_{4} .7 \mathrm{H}_{2} \mathrm{O}(0.01 \mathrm{~g} / \mathrm{L}) ;$ agar $(20 \mathrm{~g} / \mathrm{L})$; and distilled water $(1 \mathrm{~L})$ with $\mathrm{pH}$ 7.2. The medium was sterilized by autoclaving at $121^{\circ} \mathrm{C}$ for $15 \mathrm{~min}$. The medium was supplemented with $2 \%(\mathrm{v} / \mathrm{v})$ filter sterilized crude oil to serve as the only carbon and energy source (Ijah \& Abioye, 2003). The samples were serially diluted and $1 \mathrm{ml}$ aliquots was seeded in the MSM agar using the pour plate method. The medium was incubated at room temperature for 7 days. Counting was done using colony counter (TT-02 colony counter, Techmel and Techmel, USA).

\section{Extraction of genomic DNA from bacteria}

Genomic DNA was extracted from $1 \mathrm{ml}$ of 18 hours old bacterial culture using DNA extraction kit (Zymo research) following the manufacturer's instructions. The purity of DNA was determined by recording its UV absorption (260/280) spectrum on a spectrophotometer and running on $1 \%$ agarose gel electrophoresis stained with ethidium bromide to view the bands of DNA under UV light. DNA concentration was determined using $a$ Nanodrop machine (Thermo Fisher Scientific).

Polymerase chain reaction ( $P C R$ )

The purified bacterial DNAs were used for PCR 
amplification. The 16SrRNA genes were amplified by polymerase chain reaction using universal primers. PCR amplification was performed with the help of the following primer set (16SF-5'CCG AATTCGTCGACAACAGAGTTTGATCCTGGCTCA G-3' and 16SR:5'CCCGGGATCCAAGCTTACGGCTACCTTG TTACGACTT-3').

Gel purification kit was used to purify the amplified 16S rRNA gene products. The amplified products were subsequently subjected to gel electrophoresis, stained with ethidium bromide and documented by gel documentation system.

\section{Sequence determination of 16SrRNA}

The amplified 16S rRNA gene products were sequenced for identification of bacterial strain at molecular level. The clean PCR products were subjected to cycle sequencing using universal primers. The sequence of the $16 \mathrm{~S}$ rRNA was determined with a Dye terminator sequencing kit. The product was analyzed with an ABI Prism DNA sequencer (ABI). The gene sequences of each isolate obtained were compared with known 16SrRNA gene sequences in the NCBI GeneBank database using the basic local alignment search tool (BLAST) algorithm (Jyothi et al. 2012).

\section{Phylogenetic analysis}

The systematic phylogenetic tree of the isolates with high homology was constructed. The bacterial 16S rRNA gene sequences obtained coupled with the sequences retrieved from the NCBI database were aligned using Phylo F3 software.

Measurement of Degradative Activity of the isolates on crude oil

The degradative activities of each isolates were obtained by using mineral salt broth (MSB) supplemented with $2 \% \quad(\mathrm{v} / \mathrm{v})$ hydrocarbon (crude oil) sterilized using $0.22 \mu \mathrm{m}$ membrane filter were inoculated with each isolate and incubated for 14 days at $30^{\circ} \mathrm{C}$ in a shaking water bath (Boboye et al. 2010). The optical density $\left(\mathrm{OD}_{600 \mathrm{~nm}}\right)$ of each cultured medium was measured with spectrophotometer at $600 \mathrm{~nm}$ (Olukunle \& Boboye, 2012).

\section{Hydrocarbon Extraction}

The isolate that shows the highest growth rate was inoculated into a fresh MSB medium supplemented with $2 \%(\mathrm{v} / \mathrm{v})$ filter sterilized hydrocarbon (crude oil) and a control medium was left uninoculated. The hydrocarbon in the broth medium was extracted from the inoculated medium and control on Day 1 and Day 15 using solvent extraction (diethyl ether). A $10 \mathrm{ml}$ of diethyl ether was introduced into the culture broth and allowed to stand for $10 \mathrm{~min}$. With the aid of a pipette, the hydrocarbon was carefully extracted into a sterile Petri dish and air-dried overnight at room temperature to aid the evaporation of the solvent, leaving the hydrocarbon.

\section{Gas chromatography analysis of petroleum degradation}

The homogenized extract sample was transferred to $100 \mathrm{ml}$ separating funnel, and $10 \mathrm{ml}$ of the redistilled mixture of hexane: dichloromethane in ratio 3:1 was added. The separating funnel was shaken vigorously for about 2 min with periodic venting to release vapour pressure. The organic layer was allowed to separate for $10 \mathrm{~min}$ and was recovered into the $100 \mathrm{ml}$ beaker. The extract was dried by passing through the funnel containing the anhydrous sodium sulphate. The dried extract was concentrated with a steam of nitrogen gas. The concentrated extract was purified by passing the extract through the silica gel packed column after several rinsing with redistilled hexane. The mixture was concentrated to about $1.0 \mathrm{ml}$ by the steam of nitrogen gas before injecting into the entrance of the gas chromatography column.

\section{Results}

\section{Enumeration of bacteria from soil samples}

Table 1 shows the total bacterial count $(\mathrm{Cfu} / \mathrm{g})$ and count of hydrocarbon degraders $(\mathrm{Cfu} / \mathrm{g})$ in the soil sample collected from four sites. The highest total viable counts were obtained from site $4\left(17.0 \times 10^{4} \pm 2.0 \mathrm{Cfu} / \mathrm{g}\right)$ while the least total viable counts were obtained from site 1 $\left(9.0 \times 10^{4} \pm 1.7 \mathrm{Cfu} / \mathrm{g}\right)$. The highest number of hydrocarbon degrader was obtained from site $2\left(11.62 \times 10^{4} \pm 1.52 \mathrm{Cfu} / \mathrm{g}\right)$ while the least was from site $1\left(6.33 \times 10^{4} \pm 0.58\right.$ $\mathrm{Cfu} / \mathrm{g})$. 
Table 1: Population of bacteria isolated from crude oil contaminated and uncontaminated (control) soil samples

\begin{tabular}{|c|c|c|}
\hline $\begin{array}{l}\text { Sample } \\
\text { site }\end{array}$ & $\begin{array}{c}\text { Mean of total viable counts } \\
\left(\times 10^{4} \mathrm{Cfu} / \mathrm{g}\right)\end{array}$ & Hydrocarbon degrader $\left(\times 10^{4} \mathrm{Cfu} / \mathrm{g}\right)$ \\
\hline Site 1 & $9.0 \pm 1.7$ & $6.33 \pm 0.58$ \\
\hline Site 2 & $14.0 \pm 3.6$ & $11.67 \pm 1.52$ \\
\hline Site 3 & $12.0 \pm 2.0$ & $8.33 \pm 1.52$ \\
\hline Site 4 & $17.0 \pm 2.0$ & $6.67 \pm 1.53$ \\
\hline
\end{tabular}

Identification of bacterial isolates (Conventional and Molecular identification) Based on the morphological and biochemical tests carried out on the bacterial isolates, seven (7) bacteria were identified as
Pseudomonas frederiksbergensis, Alcaligenes sp. Bacillus thuringiensis, Ochrobactrum anthropi, Pseudomonas flavensces, Bacillus sp. and Pseudomonas guineae. This is presented in table 2.

Table 2: Morphological and biochemical characteristics of bacteria isolated from oil-contaminated soil

\begin{tabular}{|l|l|l|l|l|l|l|l|}
\hline $\begin{array}{l}\text { Probable } \\
\text { Bacteria }\end{array}$ & $\begin{array}{l}\text { Pseudom } \\
\text { onas } \\
\text { frederiks } \\
\text { bergensi } \\
\text { S }\end{array}$ & $\begin{array}{l}\text { Alcaligen } \\
\text { es sp. }\end{array}$ & $\begin{array}{l}\text { Bacillus } \\
\text { thuringien } \\
\text { Sis }\end{array}$ & $\begin{array}{l}\text { Ochrobactr } \\
\text { um anthropi }\end{array}$ & $\begin{array}{l}\text { Pseudom } \\
\text { onas } \\
\text { flavensce } \\
\text { S }\end{array}$ & $\begin{array}{l}\text { Bacillu } \\
\text { s sp. }\end{array}$ & $\begin{array}{l}\text { Pseudom } \\
\text { onas } \\
\text { guineae }\end{array}$ \\
\hline Gram stain & - & - & + & - & - & + & - \\
\hline Shape & Rod & Rod & Rod & Rod & Rod & Rod & Rod \\
\hline Catalase & + & + & + & + & + & + & + \\
\hline Motility & + & + & + & + & + & + & + \\
\hline $\begin{array}{l}\text { Spore } \\
\text { staining }\end{array}$ & - & - & + & - & + & - \\
\hline Indole & - & - & & - & - & & - \\
\hline Citrate & + & + & + & + & + & - & + \\
\hline $\begin{array}{l}\text { Starch } \\
\text { hydrolysis }\end{array}$ & - & + & + & - & - & + & - \\
\hline Oxidase & + & + & - & + & + & & + \\
\hline Glucose & - & - & + & - & - & + & - \\
\hline Lactose & - & - & - & A & - & - & - \\
\hline Galactose & A & AG & A & A & A & A & A \\
\hline Mannitol & A & AG & - & AG & A & - & - \\
\hline Fructose & A & - & A & A & A & A & - \\
\hline Sucrose & A & AG & - & - & A & A & - \\
\hline Pigmentation & Yellow & Yellow & Cream & Yellow & Cream & Cream & Yellow \\
\hline
\end{tabular}

KEY: + Positive, - Negative, A- Acid Production, AG - Acid and Gas Production,

Extraction of genomic DNA from bacteria

The result for the concentration and purity of samples were presented in figure 1 . The concentrations of genomic DNA extracted from bacterial isolates were between 74.8 and
$737.4 \mathrm{ng} / \mu \mathrm{l}$ and the purified DNAs have an A260/A280 ratio between 1.88 to 2.06. Strain OFBR 4 had the highest DNA concentration as shown in figure 1. 


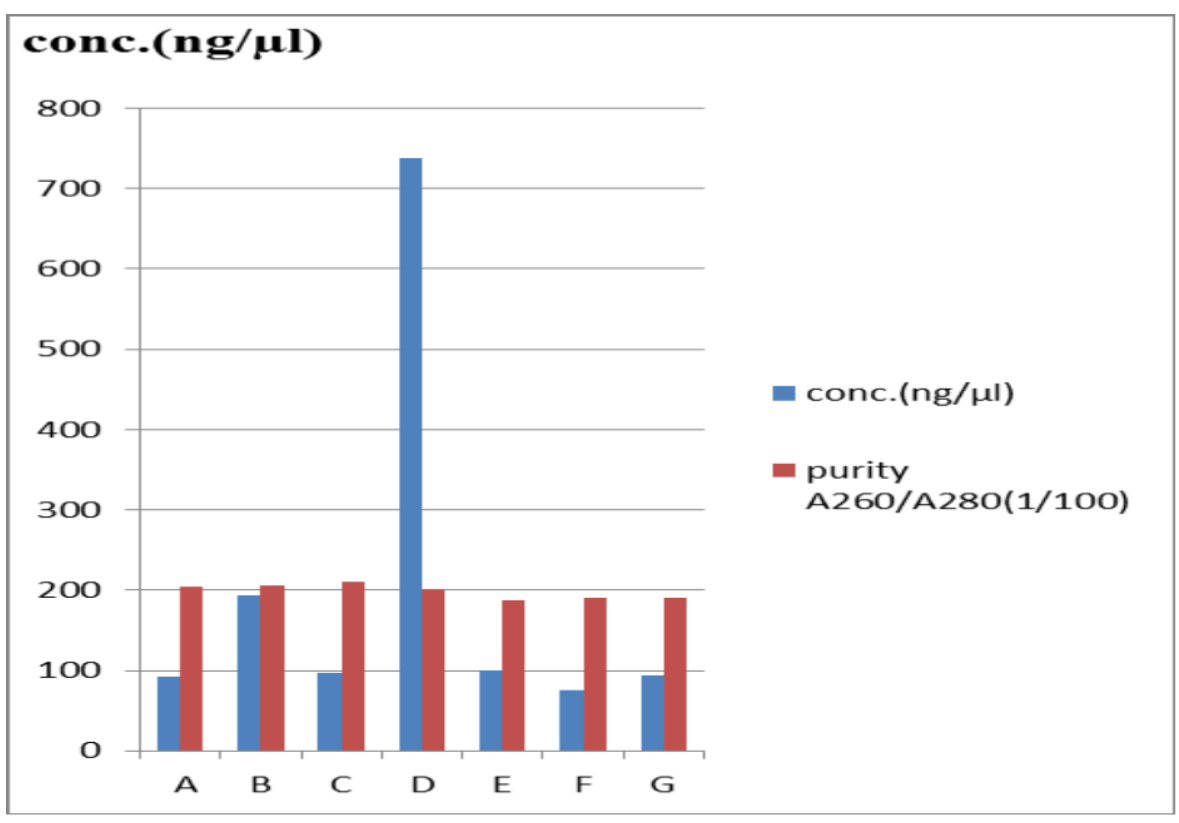

Figure 1: Bacterial DNA concentration and purity

Legend

L1 - OFBR 1- Pseudomonas frederiksbergensis

L2 - OFBR 2 - Alcaligenes sp.

L3 - OFBR 3 - Bacillus thuringiensis

L4 - OFBR 4 - Ochrobactrum anthropi

\section{PCR Amplification}

The universal primers successfully amplified the 16S rRNA gene from all the bacteria isolated from the oil-contaminated soil. The size of the 16SrRNA gene products obtained for all the seven isolates were the same as
L5 - OFBR 5 - Pseudomonas flavensces

L6 - OFBR 6 - Bacillus sp.

L7 - OFBR 7 - Pseudomonas guineae

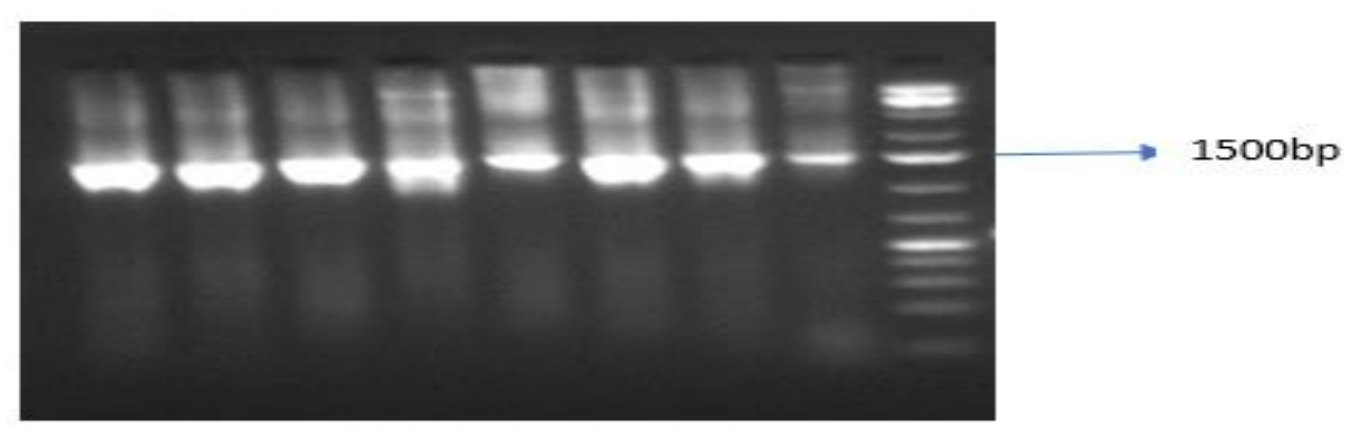

\section{L1 L2 L3 L4 L5 L6 L7}

Plate 1: PCR amplification of genomic DNA targeted to amplify the 16S rRNA gene of the oil degrading bacterial isolates in Delta State.

\section{Legend}

LO - Molecular ladder

LC - Control (E. coli)

L1 - OFBR 1- Pseudomonas frederiksbergensis

L2 - OFBR 2 - Alcaligenes sp.

there were no conspicuous variations noticeable amongst them. (Plate 1). The size of the PCR products of all isolated bacteria was approximately $1500 \mathrm{bp}$ relative to the molecular size marker. 
L3 - OFBR 3 - Bacillus thuringiensis

L4 - OFBR 4 - Ochrobactrum anthropi

Alignments of the nucleotide sequences from the Genebank

The 16S rRNA sequences of the bacteria obtained after sequencing were aligned with the genes (16S rRNA) from the other bacteria on the NCBI data bank. The complete nucleotides blast of genes from the oildegrading bacteria isolated from oil polluted soil were presented in table 3 . Alignments of these sequences showed significant similarity to previously identified bacteria and an

\section{L7 - OFBR 7 - Pseudomonas guineae}

uncultured bacterium present in oil polluted soil sample. The sequences aligned have similarity with Alcaligenes faecalis strain SH179, Alcaligenes faecalis Sub sp. Phenolicus, Bacillus thuringiensi serovar konkukian, Ochrobactrum anthropi ATCC 49188, Alcaligenes faecalis strain SH179, uncultured bacterium clone and Alcaligenes faecalis strain IVN45. These results highlight different group of bacterial genera involved in hydrocarbon degradation.

Table 3: Complete nucleotide blast of 16SrRNA genes from oil-degrading bacteria isolated from oilpolluted soil in Delta State.

\begin{tabular}{llllll}
$\begin{array}{l}\text { Bacterial } \\
\text { isolates }\end{array}$ & $\begin{array}{l}\text { Number } \\
\text { of Bases }\end{array}$ & $\begin{array}{l}\text { Homologous } \\
\text { genes }\end{array}$ & $\begin{array}{l}\% \text { identity } \\
\text { number }\end{array}$ & $\begin{array}{l}\text { Accessio } \\
\text { n. } \\
\text { numberism }\end{array}$ & Organism \\
\hline
\end{tabular}

\begin{tabular}{|c|c|c|c|c|c|c|}
\hline \multirow{4}{*}{$\begin{array}{l}\text { L1 } \\
\text { OFBR } 1\end{array}$} & \multirow[t]{4}{*}{1118} & \multirow{3}{*}{$\frac{\frac{16 \mathrm{~S}}{\text { ribosomal }}}{\text { RNA gene, }}$} & $93 \%$ & \multirow{2}{*}{$\begin{array}{l}\text { KC172O62. } \\
1\end{array}$} & \multirow{2}{*}{$\begin{array}{l}\text { Alcaligenes } \\
\text { faecalis strain }\end{array}$} & Alcaligenes faecalis \\
\hline & & & & & & $\begin{array}{lll}\text { strain } & \mathrm{SH} 179 \quad 16 \mathrm{~S} \\
\end{array}$ \\
\hline & & & & & SH179a & ribosomal RNA gene, \\
\hline & & $\begin{array}{l}\text { partial } \\
\text { sequence }\end{array}$ & & & & partial sequence. \\
\hline & 1118 & whole & $93 \%$ & $\underline{\text { NZ AUBT0 }}$ & Alcaligenes & Alcaligenes faecalis \\
\hline OFBR 2 & & genome & & 1000026.1 & faecalis sub sp. & subsp. phenolicus \\
\hline & & shotgun & & & Phenolicus & 16503 \\
\hline & & sequence & & & & $\begin{array}{l}\text { G456DRAFT scaffold } \\
00024.24 \text { C }, \text { whole }\end{array}$ \\
\hline & & & & & & genome \\
\hline & & & & & & quence. \\
\hline
\end{tabular}

\begin{tabular}{|c|c|c|c|c|c|c|}
\hline \multirow{3}{*}{$\begin{array}{l}\text { L3 } \\
\text { OFBR } 3\end{array}$} & \multirow[t]{3}{*}{947} & \multirow{3}{*}{$\begin{array}{l}\text { chromosome } \\
\text { complete } \\
\text { genome }\end{array}$} & \multirow[t]{3}{*}{$92 \%$} & \multirow{3}{*}{$\frac{\text { NC } 005957}{.1}$} & \multirow{3}{*}{$\begin{array}{l}\text { Bacillus } \\
\text { thuringiensis } \\
\text { serovar } \\
\text { konkukian }\end{array}$} & Bacillus thuringiensis \\
\hline & & & & & & serovar konkukian \\
\hline & & & & & & $\begin{array}{l}\text { str. } \\
\text { chromosome, } \\
\text { complete genome. }\end{array}$ \\
\hline
\end{tabular}

\begin{tabular}{|c|c|c|c|c|c|c|}
\hline & 486 & & $92 \%$ & NC_009668 & Ochrobactrum & Ochrobactrum \\
\hline OFBR & & $\begin{array}{l}\text { ribosomal } \\
\text { RNA gene, } \\
\text { partial } \\
\text { sequence }\end{array}$ & & .1 & $\begin{array}{l}\text { anthropi ATCC } \\
49188\end{array}$ & $\begin{array}{lr}\text { anthropi } & \text { ATCC } \\
49188 & 16 S \\
\text { ribosomal RNA gene, } \\
\text { partial sequence. }\end{array}$ \\
\hline
\end{tabular}

\begin{tabular}{|c|c|c|c|c|c|c|}
\hline $\begin{array}{l}\text { L5 } \\
\text { OFBR } 5\end{array}$ & 1118 & $\begin{array}{l}16 \mathrm{~S} \\
\text { ribosomal } \\
\text { RNA gene, } \\
\text { partial } \\
\text { sequence }\end{array}$ & $93 \%$ & $\begin{array}{l}\text { KC172062. } \\
1\end{array}$ & $\begin{array}{l}\text { Alcaligenes } \\
\text { faecalis strain } \\
\text { SH179b }\end{array}$ & $\begin{array}{l}\text { Alcaligenes faecalis } \\
\text { strain SH179 16S } \\
\text { ribosomal RNA gene, } \\
\text { partial sequence. }\end{array}$ \\
\hline L6 & 239 & $16 S$ & $79 \%$ & $\frac{\mathrm{JF} 361296.1}{68}$ & Uncultured soil & Uncultured \\
\hline
\end{tabular}




\begin{tabular}{|c|c|c|c|c|c|c|}
\hline OFBR 6 & & $\begin{array}{l}\text { ribosomal } \\
\text { RNA gene, } \\
\text { partial } \\
\text { sequence }\end{array}$ & & & bacterium clone & $\begin{array}{l}\text { bacterium clone } \\
\text { GO0VNXF07IJ3W4 } \\
\text { 16S ribosomal RNA } \\
\text { gene, } \\
\text { sequence. }\end{array}$ \\
\hline $\begin{array}{l}\text { L7 } \\
\text { OFBR } 7\end{array}$ & 456 & $\begin{array}{l}16 S \\
\text { ribosomal } \\
\text { RNA gene, } \\
\text { partial } \\
\text { sequence }\end{array}$ & $89 \%$ & $\begin{array}{l}\text { KT254066. } \\
1\end{array}$ & $\begin{array}{l}\text { Alcaligenes } \\
\text { faecalis strain } \\
\text { IVN45 }\end{array}$ & \begin{tabular}{l}
\multicolumn{3}{l}{ Alcaligenes faecalis } \\
$\begin{array}{ll}\text { strain IVN45 } & 16 \mathrm{~S} \\
\text { ribosomal } \quad \text { RNA } \\
\text { gene, } & \text { partial } \\
\text { sequence. }\end{array}$
\end{tabular} \\
\hline
\end{tabular}

\section{Conventional and Molecular Characterization}

The identities of oil degrading bacteria obtained from Mesogar community, Delta State, Nigeria are presented in table 4. It was observed that the conventional and molecular identities of isolates OFBR 2, OFBR 3 and OFBR 4 were the same, OFBR 1, OFBR 5 and OFBR 7 were at variance while OFBR 6 was assigned to uncultured bacterium clone from environmental sample.

Table 4: The identities of oil degrading bacteria by conventional and molecular characterization

\begin{tabular}{cll}
\hline Isolates & Conventional Identity & Molecular Characterization \\
\hline OFBR 1 & Pseudomonas frederiksbergensis & Alcaligenes faecalis strain SH179a \\
OFBR 2 & Alcaligenes sp. & Alcaligenes faecalis sub sp. Phenolicus \\
OFBR 4 & Ochrobactrum anthropic 3 & Bacillus thuringiensis serovar konkukian \\
OFBR 5 & Pseudomonas flavensces & Ochrobactrum anthropi ATCC 49188 \\
OFBR 6 & Bacillus sp & Alcaligenes faecalis strain SH179b \\
OFBR 7 & Pseudomonas guineae & Uncultured soil bacterium clone \\
\hline
\end{tabular}

\section{Phylogenetic Analysis}

The partial 16S rRNA gene sequence from the bacterial isolates when compared with the sequences from the database revealed that they belong to three taxonomic lineages (Figure 2). Two species belong to the beta subdivisions of Proteobacteria ( $\mathrm{A}$ and $\mathrm{B})$, one species belong to the alpha subdivisions of Proteobacteria, one specie belong to the division Firmicutes (Gram positive bacteria). One of the isolates could not be assigned to any known phylum because it has only $79 \%$ similar to the closest sequence in GeneBank (Accession No. JF361296.1), which was derived from an uncultured soil bacterium clone detected from environmental sample. All of them are members of the domain Eubacteria with gamma Proteobacteria (60\%) 
being the dominant division and alpha Proteobacteria and Firmicutes having a smaller proportion. Sequences from five (5) isolates had a similarity equal or higher than $92 \%$ with other $16 \mathrm{~S}$ rRNA sequences from the database and the remaining had less than $90 \%$ similarity. The $16 \mathrm{~S}$ rRNA analysis revealed that all isolates had similarities with the genera Alcaligenes, Ochrobactrum, Bacillus and an uncultured bacterium clone.

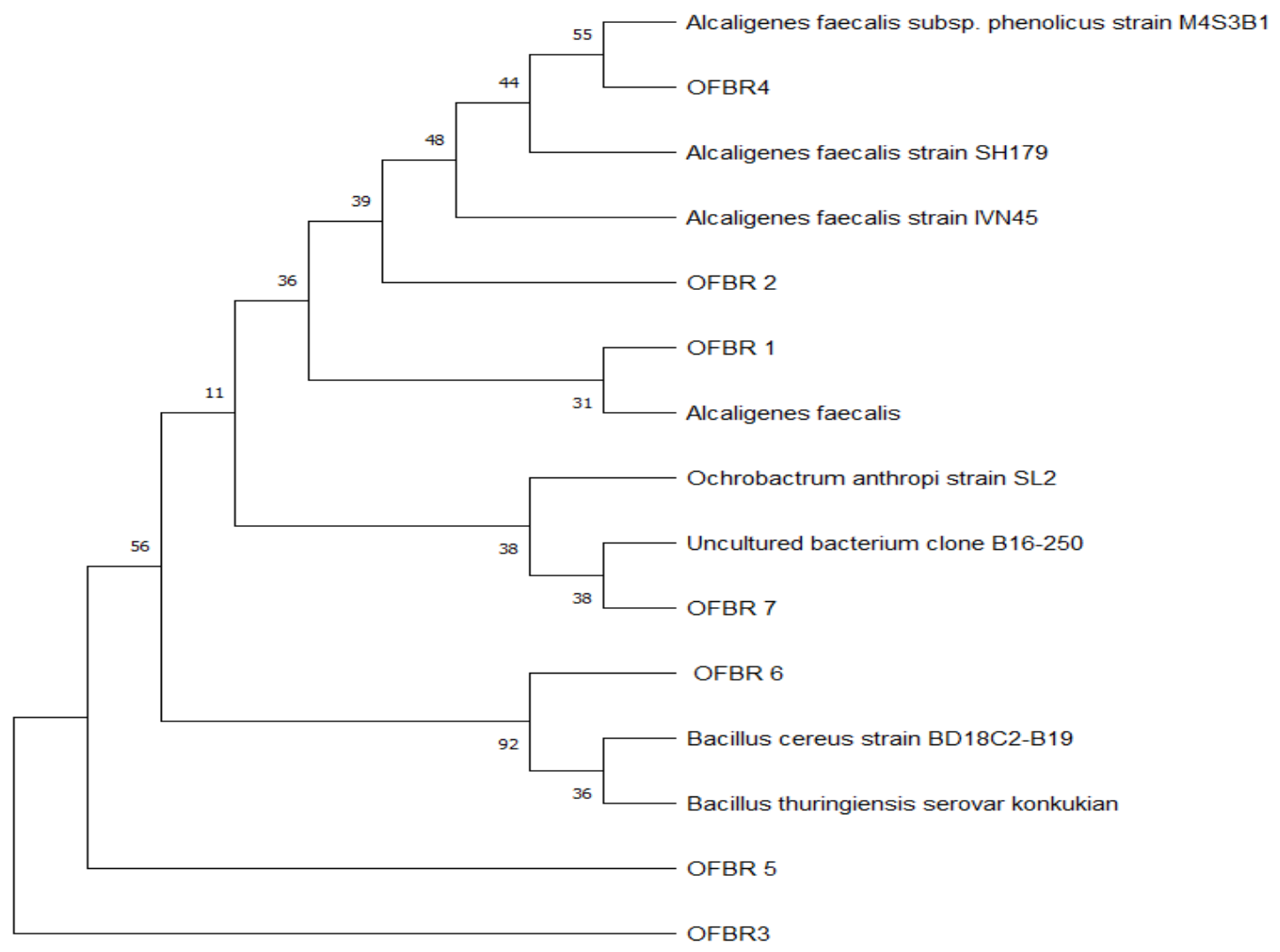

Figure 2: Phylogenetic tree based on partial 16S rRNA gene sequence of oil-degrading bacteria

Degradative ability of the isolates

All the seven bacteria isolated from contaminated soil were able to grow in the MSB medium. Strain OFBR 4 was observed to demonstrate the greatest ability to utilize crude oil. Figure (3) shows the ability

bacterial isolates to degrade crude oil based on the optical density. The degradative activity of the seven isolates revealed that they are capable of degrading crude oil although there are variations in the rates of degradation. Under similar conditions, there were differences in the degradative activity of the isolates in $2 \%$ crude oil. The incubation period had effect on the degrading activity of the seven isolates degraded crude oil, suggesting that they have similar gene that encodes for hydrocarbon degradation in their genetic make-up. 


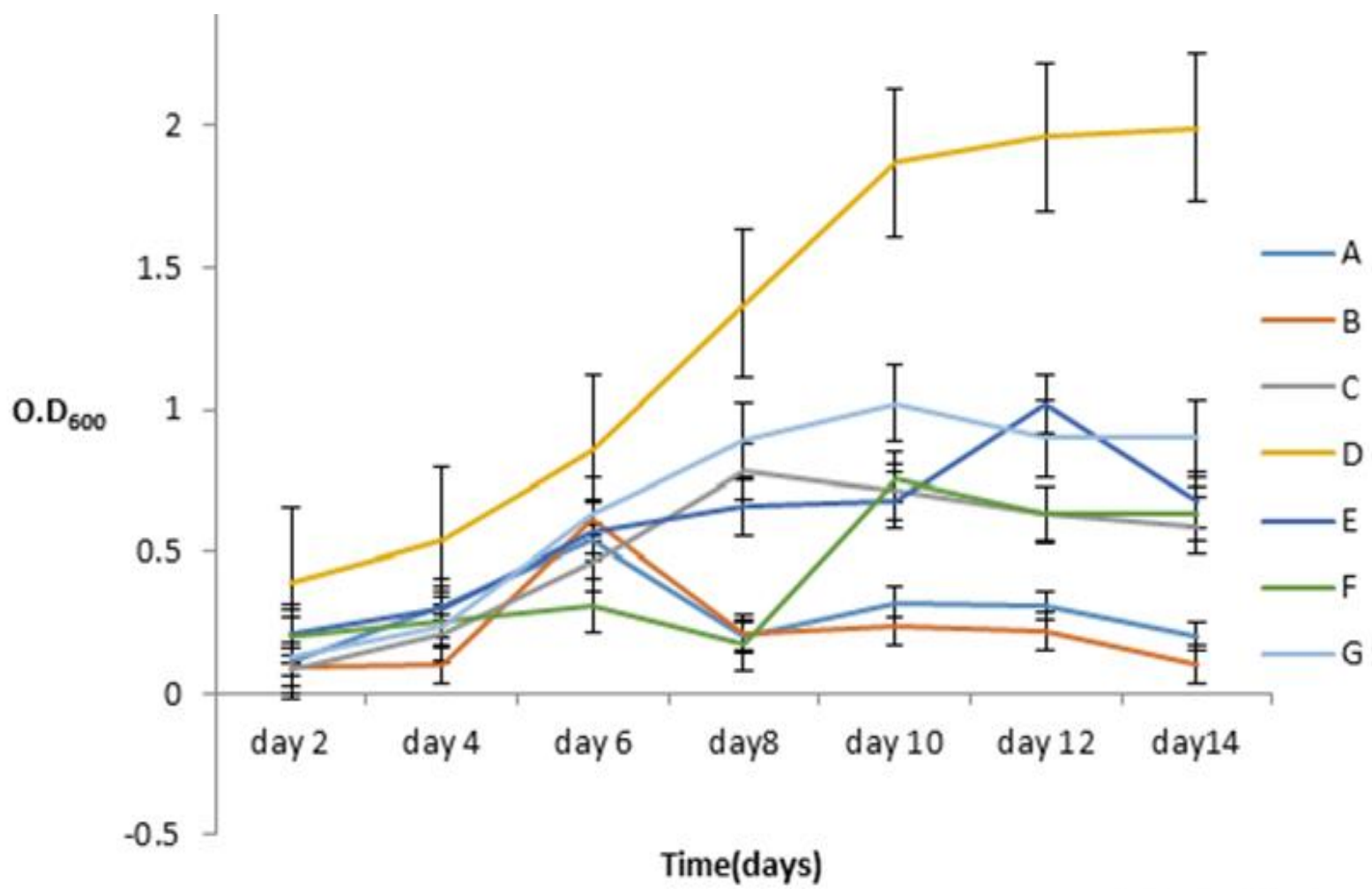

Figure 3: Oil-degrading activity of bacterial growth on mineral salt medium supplemented with $2 \%$ crude oil.
Legend
A - OFBR 1
B - OFBR 2
C - OFBR 3
D - OFBR 4

$$
\begin{aligned}
& \mathrm{E}-\text { OFBR } 5 \\
& \mathrm{~F}-\text { OFBR } 6 \\
& \mathrm{G}-\text { OFBR } 7
\end{aligned}
$$

Gas chromatography analysis of hydrocarbon degradation

The total petroleum hydrocarbon (TPH) in the control was determined to be $9.88134 \mathrm{e} 5$ with twenty different hydrocarbons. The retention time for the first eluted hydrocarbon was $8.993 \mathrm{~min}$ and the amount of hydrocarbon eluted was $2.982964 \mathrm{mg} \mathrm{Kg}-1$ (figure 4). After the first day of biodegradation, the total petroleum hydrocarbon (TPH) had reduced to 9.30857e5 and a reduced retention time with a reduction in the amount of hydrocarbon that eluted the column at that particular time (figure 5). The different types of aromatic hydrocarbon present had been reduced to eighteen. After the fifteen day of biodegradation, Strain OFBR 4 had been able to degrade up to $75.3 \%$ of the total petroleum hydrocarbon (figure 6).

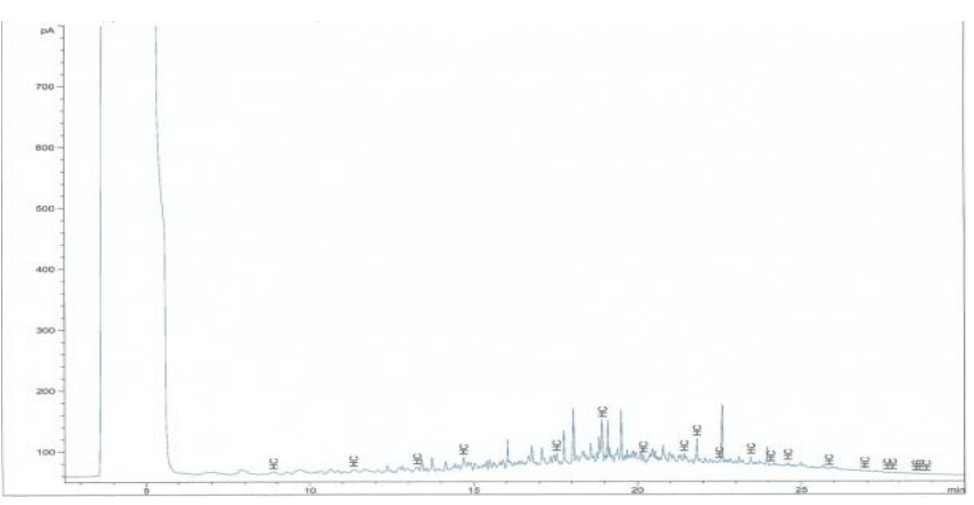

Figure 4: Chromatogram of control (MSM + crude oil) 


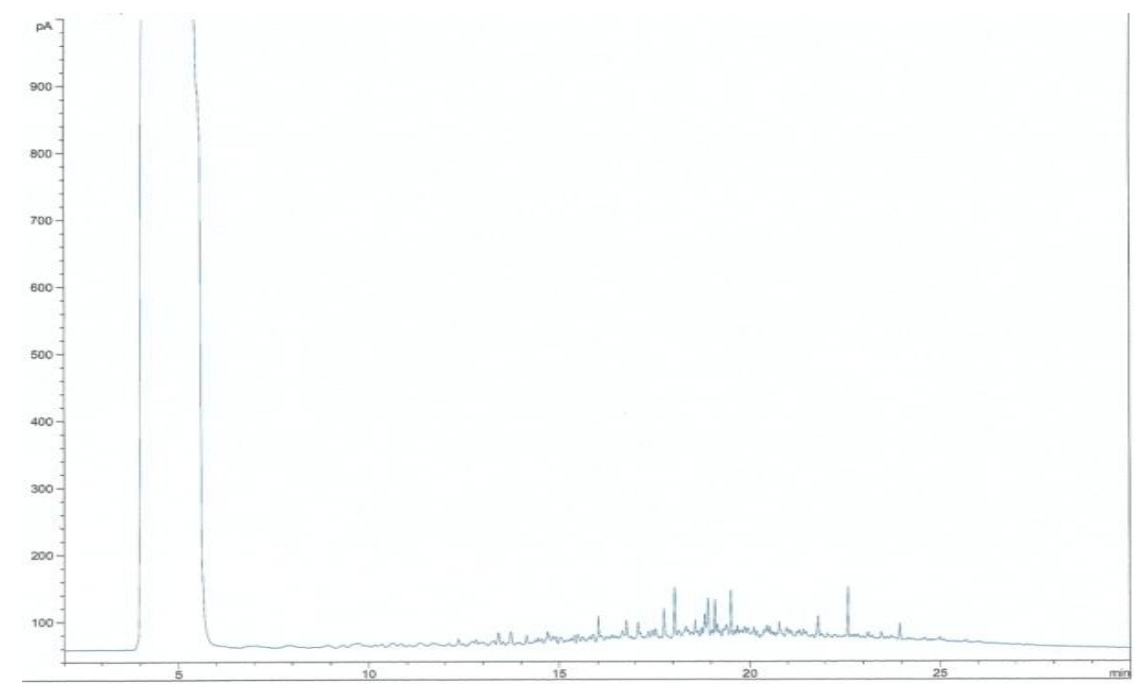

Figure 5: Chromatogram of oil after 24hours of Strain OFBR 4 on MSM + oil

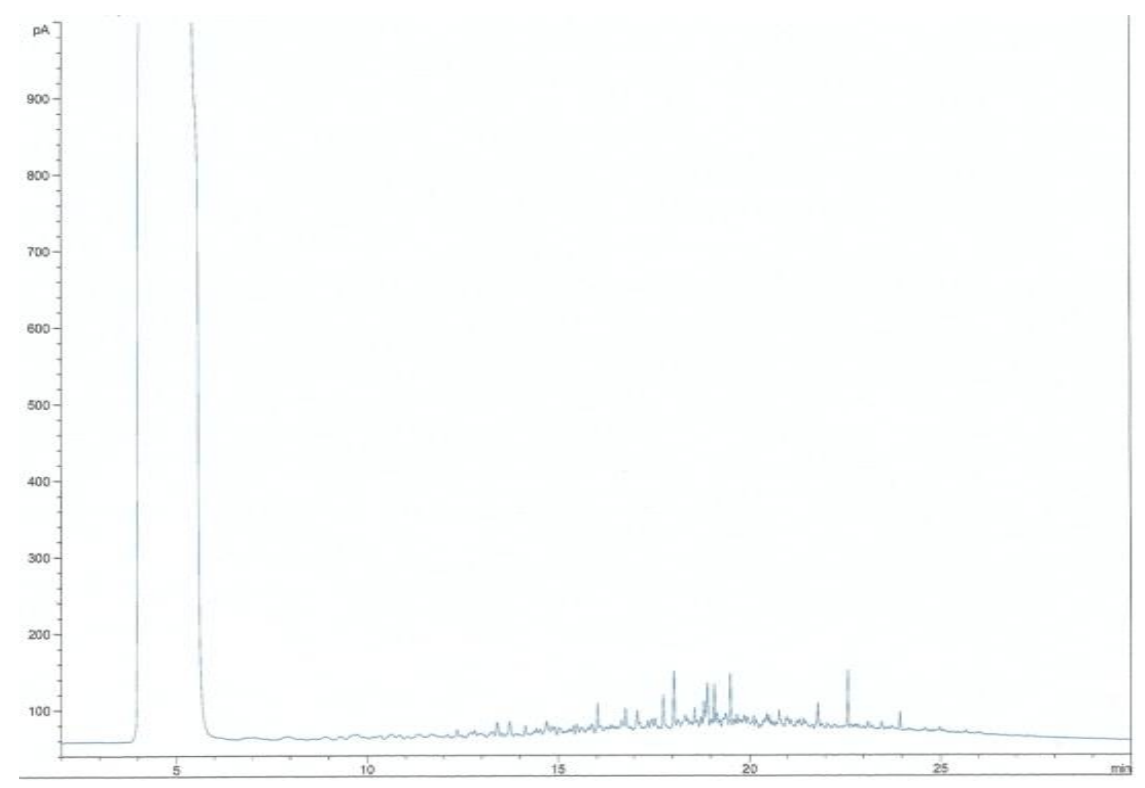

Figure 6: Chromatogram of crude oil after 15 days of Strain OFBR 4

\section{Discussion}

The population of bacteria and hydrocarbon degraders in oil polluted and non-polluted soils degrading bacteria in the polluted soil shows clearly that the indigenous bacteria were carrying out their metabolic activity using the oil supplemented in the growth medium as the sole source of carbon and energy. The in Mesogar community, Delta State confirms the ubiquity of bacteria. The presence of these oil-

activities of these bacteria could be responsible for the bioremediation of the environment which is in agreement with the findings of Ojo (2006). 
The conventional methods of identification revealed seven (7) bacteria in the soil samples from Mesogar community, Delta State. They were: Pseudomonas frederiksbergensis, Alcaligenes sp., Bacillus thuringiensis, Ochrobactrum anthropic, Pseudomonas flavensces, Bacillus sp. and Pseudomonas guineae. Previous studies have reported species of Pseudomonas sp., Alcaligenes, and Bacillus to be implicated in hydrocarbon degradation by a group of researchers (Oboh et al. 2006; Boboye et al. 2010). The identity of only seven (7) isolates seemed ridiculously small in number. This could be adduced to the fact that not all bacteria are amenable to laboratory conditions and may find it difficult to be cultured.

The molecular technique of identification of bacteria used in this study was based on the conserved sequence of the 16S rRNA genes of various bacteria according to Farrelly et al. (1995). The results obtained from the conserved sequence of the 16S rRNA coupled with the nucleotide sequence, revealed that the isolated bacteria are Alcaligenes faecalis strain SH179a, Alcaligenes faecalis sub sp. Phenolicus, Bacillus thuringiensis serovar konkukian, Ochrobactrum anthropi ATCC 49188, Alcaligenes faecalis strain SH179b, Uncultured soil bacterium clone and Alcaligenes faecalis strain IVN45. The bacteria identified from the same samples using conventional methods are Pseudomonas frederiksbergensis, Alcaligenes sp., Bacillus thuringiensis, Ochrobactrum anthropi, Pseudomonas flavensces, Bacillus sp. and Pseudomonas guineae. Wackett (2003) reported that Pseudomonas species is the most extensively studied owing to their ability to degrade so many different contaminants. In this study, Pseudomonas species was not detected by molecular characterization but was found to have remote identity with Alcaligenes species (Table 4). This corroborates the findings of Pace (1997) that molecular techniques will reveal information about metabolic life style of microorganisms which are not amenable to pure cultures. Alcaligenes faecalis SH179a and Alcaligenes faecalis $\mathrm{SH} 179 \mathrm{~b}$ are similar even to the strain level but exhibit different phenotypic characteristics. This may be due to phenotypic adjustments for adaptation in the polluted environment. Three of the isolates have the same number bases hence, their species identity was similar but of different strains. Adesanya et al. (2004) isolated Bacillus thuringiensis from Bitumen contaminated sediments. Bhattacharya et al. (2015) reported to have isolated Ochrobactrum sp. with the capability of degrading hydrocarbons in different waste lubricant oil sources. They also show that Ochrobactrum sp. could degrade several kinds of hydrocarbon like naphtalene, xylene, diesel, and kerosene. Ibrahim (2016) also reported biodegradation of used engine oil by novel strains of Ochrobactrum anthropi HM-1 isolated from oil-contaminated soil. The low percentage similarities $(79 \%$ - 93\%) that the bacterial isolates have with the blast mean that they have remote homologous to each other. The remote identity scores obtained in this study cannot really place the bacteria at both the genus and species level). They may therefore be regarded as novel bacteria (Olukunle et al. 2019). This is evident in the genus of bacteria obtained from the molecular characterization and the conventional identification in this study.

In constructing the phylogenetic tree, the tree was rooted by assigning a root to the tree to show the evolutionary pathway. The tree showed the closeness of the isolates based on similarity in the nucleotide sequences. The molecular method of identifying bacteria to gene level have been found to be more reliable than the conventional approaches because the technique relies on examination of genetic diversity of isolates. Molecular data generated in this research have shown to be more suited to phylogenetic studies than phenotypic data. The partial 16S rRNA gene sequence from the bacterial isolates when compared with the sequences from the database revealed that they belong to three taxonomic lineages (Figure 2). Two species belong to the beta subdivisions of Proteobacteria (A and $B$ ), one species belong to the alpha subdivisions of Proteobacteria, one specie belong to the division Firmicutes (Gram positive bacteria). One of the isolates could not be assigned to any known phylum because it has only $79 \%$ similar to the closest sequence in GeneBank (Accession No. JF361296.1), which was derived from an uncultured soil bacterium clone detected from environmental sample. All of them are members of the domain Eubacteria with gamma Proteobacteria $(60 \%)$ being the 
dominant division and alpha Proteobacteria and Firmicutes having a smaller proportion. Sequences from five isolates had a similarity equal or higher than $92 \%$ with other $16 \mathrm{~S}$ rRNA sequences from the database and the remaining had less than $90 \%$ similarity. The 16S rRNA analysis revealed that all isolates had similarities with the genera Alcaligenes, Ochrobactrum, Bacillus and an uncultured bacterium clone.

The test for the degrading capabilities of these bacteria on crude oil showed that the bacteria isolated from the soil samples were able to multiply within the days of study, indicating their ability to utilize the oil for their growth and development, hence the concomitant increase in the turbidity of the mineral salt broth (MSB). This gradual increase in the turbidity of the broth indicates bacterial growth and activities (Olukunle \& Boboye, 2012). At day 6 , all the isolates were effectively in their exponential growth phase and optical density was very high. At day 10 , all isolates tend to have reached the peak of their exponential phase as shown in Figure 2. At day 12, all isolates had entered the stationary phase where there was no longer multiplication of cells, with the exception of isolate D (OFBR 4) and isolate E (OFBR 5) that continued to multiply. At day 14 , the optical density value for all isolates decreased with an exception to isolate $D$ (OFBR 4) that continued to increase. The degradation of crude oil, mostly between days 2 and 10 and gradual decline in the concentration of the broth suggests decrease in the bacterial population and that some components of the oil had been degraded, mostly between days 12 and 14 . OFBR 4 shows the highest degrading capability while OFBR 1 shows the lowest degree of degradation. Doan et al. (2017) reported the degradative ability of Ochrobactrum sp. while Ezekoye et al. (2018) demonstrated that Proteobacteria played a key role in the remediation of a polluted site with a shift in the bacterial community during the remediation process in a study on field metagenomics of bacterial community involved in bioremediation of crude oil polluted soil.

The spectrum of peaks that appeared in the chromatogram shows how the hydrocarbons are being eluted from the column at different times. The small reduction in hydrocarbon for the first day indicates that the bacterium is still adjusting to the new environment. The chromatogram shows that the relative abundance of the peak had reduced considerably. There was a depletion of total area of chromatogram of various component of oil in agreement with the findings of Dasgupta et al. (2013). The shorter chain hydrocarbon in the crude oil are more easily degraded more rapidly than the longer ones. This correlates with the study of Shaopeng et al. (2013) on the characterization of oildegrading bacteria from oil contaminated soil. The type of hydrocarbon degraded was not determined. Further studies may employ the use of Gas Chromatography Mass Spectrometry (GC-MS). The high rate of hydrocarbon degradation by OFBR 4 could be as a result of the massive growth and enzyme production responses during the growth of the isolates (Bogan \& Lamar, 1996). Ochrobactrum anthropi is a de-emulsifying bacterium that has been reported to be associated with crude oil contaminated soil. Suspension of the strain had been reported by Mohebali et al. (2015) to be capable of efficient breaking up of multiple water-oil emulsions containing crude oil. Also, Ibrahim (2016) reports its ability to produce biosurfactant, a biological surface-active agent that interacts with oily layers.

\section{Conclusion}

In this study, OFBR 4 which has remote homologous with Ochrobactrum anthropi ATCC 49188 shows the highest degrading capability. It can be established that the identities of the bacteria are more authentic using molecular identification. The Gas Chromatography analysis revealed that there was depletion of total area of chromatogram of various component of oil by OFBR 4 . The bacteria isolated in this study are good candidates for bioremediation of oil polluted sites. The use of molecular methods for rapid and accurate detection of diverse strains of hydrocarbondegraders is of utmost necessity in bioremediation especially in identifying the exact bacterial strain responsible for oildegradation. Further research could be done on metagenomics of oil polluted soils in order to give the bacterial community of the oil polluted soils. In addition, the type of crude oil degraded could be determined by Gas Chromatography Mass Spectrometry (GC-MS). 


\section{References}

Adesanya O.O., Osho A., Durugbo E., Akinyemi O. and Shokunbi O. (2004). Hydrocarbon degradation potentials of bacterial species isolated from Bitumen contaminated water and sediments in Ilubirin, Temidire camp and Agbabu communities of Ondo state, South West Nigeria. J. Int. Acad. Res. Multidiscip., 2(5):239-248.

Ainon, H., Amir, R., Raja, F. H., and Noor, A. Y. (2010). Isolation and Characterisation of Bacteria Degrading Sumandak and South Angsi. J. Sains Malaysiana, 161-168.

Asadirad, M. H. A., Mazaheri Assadi, M., Rashedi, H. and Nejadsattari, T. (2016). Effects of Indigenous Microbial Consortium in Crude Oil Degradation: A Microcosm Experiment. International J. Env. Res., 10(4):491-498.

Bhattacharya, M., Biswas, D., Sana, S. and Datta, S. (2015). Biodegradation of waste lubricants by a newly isolated Ochrobactrum sp. C1. 3 Biotech. 5:807-817.

Boboye, B., Olukunle, O. F., and Adetuyi, F. C. (2010). Degradative activity of bacteria isolated from hydrocarbon-polluted site in Ilaje, Ondo State, Nigeria. Afr. J. Micro. Res., 4(23): 2484-2491.

Bogan, B. W. and Lamar R. T. (1996). Polycyclic aromatic hydrocarbon-degrading capabilities of Phanerochaetelaevis HHB-1625 and its extracellular ligninolytic enzyme. Appl. Env. Microb., 62:1597-1603.

Chang, S. E., J. Stone, K. Demes, and M. Piscitelli. (2014). Consequences of oil spills: a review and framework for informing planning. Ecol. and Soc., 19(2): 26.

Dasgupta D., Ritabrata G. and Tapaskk (2013). Biofilm mediated enchanced crude oil degradation by isolated microorganisms. Dept. Biol. Sci.:1- 13.

Doan, C. D. P., Sano, A., Tamaki, H., Pham, H. N. D., Duong, X. H. and Terashima, Y. (2017). Identification and biodegradation characteristics of oil-degrading bacteria from subtropical Iriomote Island, Japan, and tropical Con Dao Island, Vietnam. Tropics, 25(4):147-159.
El Hanafy, A. A., Anwar, Y., Mohamed, S. A., Al-Garni, S. M. S, Sabir, J. S. M, Abu Zinadah, O.A.H, and Ahmed, M. M. (2015). Isolation and Molecular Identification of Two Fungal Strains Capable of Degrading Hydrocarbon Contaminants on Saudi Arabian Environment. Int. J. Bioeng. and Life Sci., 9(12): 1215-1218.

Ezekoye, C. C., Chikere, C. B. and Okpokwasili, G. C (2018). Field Metagenomics of Bacterial Community Involved in Bioremediation of Crude Oil-Polluted Soil. J. Bioremed. Biodegrad., 9(5):1-10.

Farrelly, V., Rainey, F. A. \& Stackebrandt, E. (1995). Effect of genome size and rrn gene copy number on PCR amplification of $16 S$ rRNA genes from a mixture of bacterial species. Appl. Env. Microb. 61, 2798-2801.

Fathepure, B. Z. (2014). Recent studies in microbial degradation of petroleum hydrocarbons in hypersaline environments. Front. Microb., 5(173):1-16.

Gautam, P. and Vimal, A. (2014). Phylogenetic Analysis of Selected Lactic Acid Bacteria by Using Bioinformatic Tools. Int. J. Eng. Tech. Res. (IJETR), 2(8):53-58.

Gopinathan, R., Prakash, M., and Bharanthirajan, B. (2012). An experimental study for crude oil biodegradation in contaminated soil. Int. J, Curr. Microb. Appl. Sci., 1(1): 12-16.

Hamzah, A., Rabu, A., Azmy, R. H. and Yussoff, N. A. (2010). Isolation and Characterization of Bacteria Degrading Sumandak and South Angsi Oils. J. Sains Malaysiana, 39(2): 161-168

Hamzah, A., Tavakoli, A. and Rabu, A. (2011). Detection of toluene degradation in bacteria isolated from oil contaminated soils. J. Sains Malaysiana, 40(11): 1231-1235.

Hugenholtz, P., and Goebel, B. M. (2001). The polymerase chain reaction as a tool to investigate microbial diversity in environmental samples. In P. A. Rochelle (Ed.), Env. Microb.: Protocols and Applications (pp. 31-40). Wymondham, UK: Horizon Scientific Press. 
Ibrahim, H. M. M. (2016). Biodegradation of used engine oil by novel strains of Ochrobactrum anthropic $\mathrm{HM}-1$ and Citrobacterfreundii $\mathrm{HM}-2$ isolated from oilcontaminated soil. Biotech., 6:226.

JeromeJeyakumar, J. (2013). A study of phytochemical constituents in Caralluma umbellate by GC-MS Analysis. Int. J. Phar. Sci. Inv., 37-41.

Jyothi. K., Babu, S. K., Clara, N. K. and Kashyap, A. (2012). Identification and Isolation of Hydrocarbon degrading bacteria by Molecular Characterization. Helix, 2: 105111.

Kachienga, L., Jitendra, K. and Momba, M. (2018). Metagenomic profiling for assessing microbial diversity and microbial adaptation to degradation of hydrocarbons in two South African petroleum contaminated water aquifers. Scientific Reports, 8:7564

Mohebali, G., Kaytash, A. and Etemadi, N. (2015). Experimental breaking of water/ oil emulsions aimed at development of a water separation bacterial process in oil industries. Iran. J. Sci. and Tech., 98: 120-128.

Oboh, B. O, Ilori . M.O., Akinyemi, J. O. and Adebusoye S. A. (2006). Hydrocarbon Degrading Potentials of Bacteria Isolated from a Nigerian Bitumen (Tarsand) Deposit. Nat. \& Sci., 4(3): 51-57.

Ojo, O. A. (2006): Petroleum-hydrocarbon utilization by native bacterial population from wastewater carnal Southwest Nigeria. Afr. J. Biotech. 5 (4) 333-337.

Olukunle O. F. and Boboye, B. (2012). Phylogenetic analysis of Oil-degrading Bacteria Associated with Polluted Sites in River State, Nigeria. Arch. Appl. Sci. Res., 4(4): 1600-1608.

Olukunle, O. F. (2013). Characterization of Indigenous Microorganisms Associated with Crude Oil Polluted Soils and Water using Traditional Techniques. Microb. J., 3: 1-11.

Olukunle, O. F. (2019). Molecular Identification of Crude Oil-Degrading Bacteria and Screening for Catechol 2, 3 Dioxygenase (C230) Gene. Biotech. J. Int., 23(4): 1-14.
Osuagwu, E. Olaifa, E. (2018). Effects of Oil Spill on Fish Production in the Niger Delta. PLoS ONE, 13 (10): e0205114.

Oyetunji, B. (2013). Oil Price and Exchange Rate Volatility in Nigeria. Undergraduate Thesis.

Romanus, A. A., Ekundayo, A. O, Aigere, S. P. and Okwu G. I. (2015). Bacterial degradation of petroleum hydrocarbons in crude oil polluted soil amended with cassava peels. Am. J. Res. Comm., 3(7): 99- 118.

Pace, N. R. (1997). A molecular view of microbial diversity and the biosphere, Science 276: (5313) 734-740.

Saleh, A. B., Ghazali, F.M., Abd Rahman, Z. R. N. and Basri, M. (2003). Bioremediation of Petroleum Hydrocarbon Pollution. Ind. J. Biotech., 2: 411-425.

Shaopeng, Y., Qiuyu W., Lina, Q. and Cong, L. (2013). Characterization of Oil Degrading Bacteria from Oil. Contaminated Soil and Activity of their Enzyme. Biotech. \& Biotech. Equip., 27:4, 3932-3938

Unimke, A.A, Mmuoegbulam, A. O and Anika, O. C (2018). Microbial Degradation of Petroleum Hydrocarbons: Realities, Challenges and Prospects. Biotech. J. Int., 22(2):1-10.

Vivek, K. C. and Debajit, B. (2011). Isolation and Molecular Characterization of Hydrocarbon-degrading bacteria from tannery effluent. Int. J. Pollut. \& Env. Sci., I1(2): ISSN 2231-4490.

Wackett, L. P. (2003). Pseudomonas putida - A versatile biocatalyst. Nat. Biotech., 21:136138.

Willey, J. M., Sherwood L. M. and Woolverton C. J. (2008). Biodegradation and Bioremediation by Microbial Communities. Prescott, Harley, and Klein's Microbiology, 7th ed. McGraw-Hill Companies, New York. Pp. 1060 ISBN 978-0-07-299291-5.

Varjani, S. J (2017). Microbial degradation of petroleum hydrocarbons. Biores. Tech., 223: 277-286. 